\title{
Microfinance Institutions and MSMEs Performance in the Framework of Poverty Alleviation
}

\author{
L. Layyinaturrobaniyah*, M. Anwar, S.R. Nidar, Y.R. Nababan \\ Universitas Padjadjaran \\ Bandung, Indonesia \\ layyinaturrobaniyah@unpad.ac.id
}

\begin{abstract}
Microcredit is one of the microfinance services of Microfinance Institutions, which is believed to be an effective tool to alleviate poverty through the use of loans by establishing micro, small and medium enterprises. With the existing effort, people are expected to earn income so that they can meet their daily needs and improve their welfare. This study aims to determine the effect of microcredit and the performance of MSMEs on poverty alleviation in affected people around Jatigede Reservoir, Sumedang, West Java. Samples from this research are people affected by Jatigede dam that spread in five Sumedang sub-districts namely Jatigede, Jatinunggal, Wado, Darmaraja and Cisitu which amounts to 100 people. Data collection is done by filling out a questionnaire directly to the community. To see the effect of micro credit and MSMEs performance on poverty alleviation, this study uses PLS SEM analyst with SmartPLS version 3.0 for windows. The results of this study indicate that microcredit and the performance of MSMEs simultaneously affect the level of poverty. Partially, micro credit and MSMEs performance also have a negative and significant impact on poverty level.
\end{abstract}

Keywords-MSMEs Performance; Microfinance; Poverty Alleviation

\section{INTRODUCTION}

Poverty is still the main problem faced in Indonesian state both in urban and rural areas. Poverty occurs due to low education, laziness, limited natural resources, limited employment, limited capital and family burdens [1]. Based on data obtained from the Indonesian Central Bureau of Statistics (BPS), the number of poor people in Indonesia reached 27.77 Million people or $10.64 \%$ in March 2017, this figure only decreased about $0.22 \%$ or about 240 thousand people from March 2016

One of the areas in Indonesia that are facing poverty is Sumedang regency, West Java. Based on data from BPS West Java, the percentage of poverty in Sumedang regency reached $10.57 \%$ or about 120.60 thousand inhabitants. This poverty was influenced by the construction of a reservoir in Jatigede sub district, Sumedang which drowned 28 villages in five subdistricts causing 10,924 families lost their homes and agricultural land, including 1382 hectares of forest and cultural reserves.
One of the solutions in poverty alleviation is the formation of productive efforts in the community both in the micro, small and medium scale (MSMEs). Established businesses help communities earn income while providing new jobs. The establishment of easy and small capital makes MSMEs widely known to the people of Indonesia and the number continues to increase from year to year. Based on BPS, the number of MSMEs until 2016 has reached 55.2 million with the contribution of MSMEs to GDP of $60.34 \%$ on and the employment rate up to $97.22 \%$. This shows that the potential of MSMEs in eradicating poverty in Indonesia is very big.

However, the development of MSMEs in Indonesia has not been accompanied by adequate financing institutions, 60-70\% of MSMEs in Indonesia do not have access to banks. This can certainly hamper the development of MSMEs. One of the alternative financings of MSMEs is through Microfinance Institution (MSI). This institution was created specifically to serve the finances in the form of microcredit of the poor as well as community micro-enterprises. This MFI becomes very useful because of its more flexible, simple and non-collateral financing. The microfinance program itself has been proven to eradicate poverty in Bangladesh, a program pioneered by Yunus [2] through the Grameen Bank has delivered it to the Nobel Peace Prize in 2006.

\section{LITERATURE REVIEW}

Several studies on the role of Microfinance Institutions and MSMEs in overcoming poverty have been carried out both at home and abroad [3]. There is a relationship between business profitability and bank loans and there is also a significant relationship between business profitability and business size. Moreover, microcredit has a positive effect on the benefits of micro-enterprises [4].

Another study in Indonesia by Karay [5] shows that financial and marketing variables are very influential in empowering MSEs. Meanwhile, MFIs have contributed to poverty reduction in Pakistan, where people who borrow at the Bank can increase their income through the use of loans obtained [6]. Imtiaz, et al [7] who conducted research in Pakistan stated that poverty has been reduced by providing access to finance to the public. 
In its development, MFIs have been tested to reduce poverty by increasing household incomes, increasing the role of women in economic development [8]. The microcredit channeled can positively affect the achievement of home industry where credit increase, increase capital and increase production value [9].

Departing on the success of the MFI, the authors are interested to examine the effect of MFIs, particularly on microcredit services to the performance of MSMEs around the Jatigede Reservoir which ultimately can reduce the poverty rate of the Affected People.

Microfinance institutions in both formal and informal form provide microfinance services in the form of microcredit, micro saving, and microinsurance. MFI as an institution that provides financial services to the poor and is a very important role in community empowerment.

One of the steps of community empowerment is micro, small and medium-scale or called MSMEs. The empowerment of the economic community or small business energy such as microcredit [10]. Therefore, the MFI will provide financial services in the form of microcredit that will be used as working capital for MSMEs. Access to capital is what is expected from tertiary factors such as production, labor, capital, equipment and business equipment [3]. Hopefully, MSMEs can perform well with microcredit. The performance of MSMEs is good if the profit level is high (higher profit), sales increase (higher growth in sales) and the increase of empowered workforce (empowerment) [3].

Through income and profit obtained by MSMEs, the existing business can grow and develop better. This is a new job in the community, both business owners and their members get responses to life. Increasingly, the more income that allows them to find more and better, clean water, sanitation, health, housing, education, and information. Specifically has a different rate set by the World Bank that is US \$ 1.25 per day or in the range of US \$ 1 - US \$ 2 per day.

Based on the thinking process above, the writer then makes the following frame of mind.

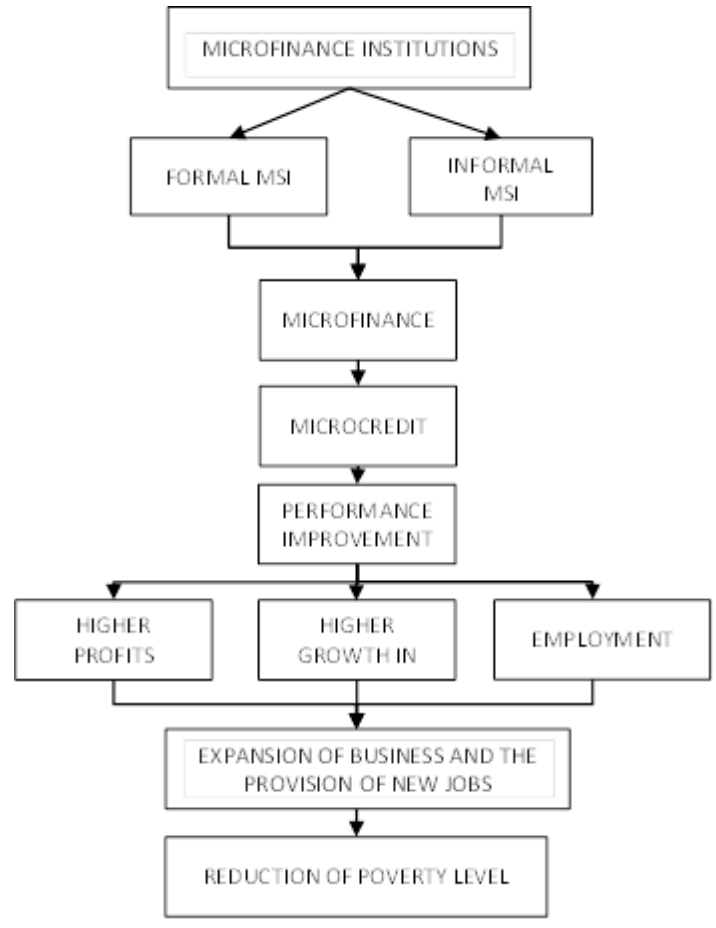

Fig. 1. Research framework.

Based on Framework Thought mentioned above, the research hypothesis to be tested are:

H.1. Microcredit and MSMEs performance simultaneously affect the level of poverty of the Affected people in the area around Jatigede Reservoir, Sumedang

H.2. Microcredit has a negative effect on Poverty Level of Affected people around Jatigede Reservoir Sumedang

H. 3 MSMEs performance has a negative effect on Poverty level of Affected people around Jatigede Reservoir Sumedang.

\section{METHOD}

The method used in this research is a descriptive and verificative method. The type of research applied is survey research where the primary data by asking people to answer some questions in the questionnaire. This study uses time horizon with a cross-sectional survey or one-time survey method that is studying the object of research in a certain period of time only. The respondents of this research are 100 people who are Jadigede Hemorrhagic Fever spread over five districts, namely: Jatigede, Jatinunggal, Wado, Darmaraja, and Cisitu, have businesses in micro, small and medium scale, have or are using credit obtained from the Institute formal and informal microfinance.

This study uses PLS SEM analysis with SmartPLS version 3.0 for windows. The PLS-SEM analysis consists of three stages of outer model analysis, inner model analysis, and hypothesis testing. 


\section{RESULT AND DISCUSSION}

Based on the descriptive analysis of the microcredit services used by the affected people community has been very good in terms of terms, amount, interest rate, loan duration and payment period. However, the performance of MSMEs run by the community is in the category of less good, because the business runs less smoothly, the aging does not increase, so the profit is low and there is no additional workforce in the business. The poverty rate of the AHs has improved considerably. This indicates that the presence of microcredit and MSMEs has brought about a change in the poverty rate of affected people. This good condition needs to be improved again with the use of microcredit and the performance improvement of MSMEs in the future.

To answer the verificative analysis, use PLS SEM analysis the following structural models are used and processed with SmartPLS Version 3.0 for windows.

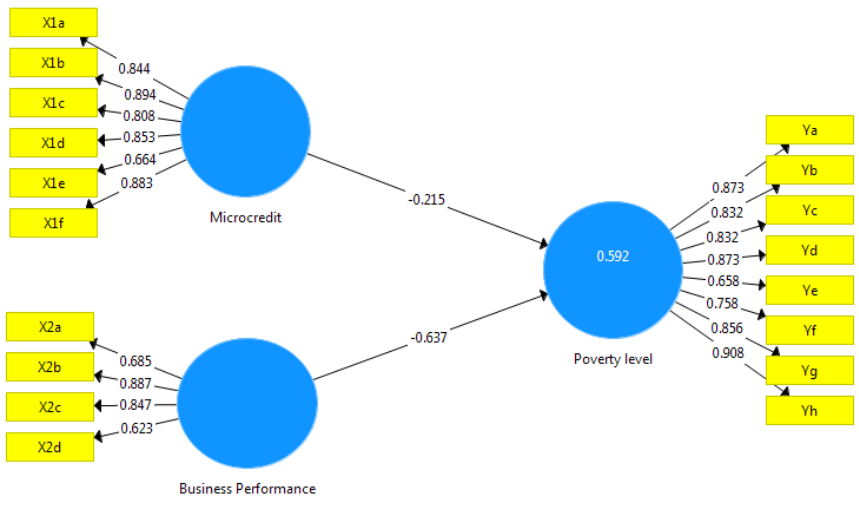

Fig.2. Structural Model.

Based on verification analysis about the influence of microcredit and the performance of MSMEs to the level of poverty. Microcredit variable and MSMEs performance simultaneously affect poverty level variable as much as $59.2 \%$. This means that $59.2 \%$ of poverty alleviation is influenced by microcredit and community-owned MSMEs, the remaining $40.8 \%$ is influenced by other factors not investigated such as government aid/grant factors, other community empowerment programs, natural resource factors, etc.

TABLE 1. HYPOTHESIS TESTING.

\begin{tabular}{lllll} 
& $\begin{array}{l}\text { Original } \\
\text { Sample }\end{array}$ & $\begin{array}{l}\text { t- } \\
\text { Statistic }\end{array}$ & $\begin{array}{l}\text { t- } \\
\text { hitung }\end{array}$ & P-values \\
& & & & \\
\hline $\begin{array}{l}\text { Microcredit } \rightarrow \text { Poverty } \\
\text { Level }\end{array}$ & -0.215 & 3.462 & 1,96 & $0.000 * * *$ \\
$\begin{array}{l}\text { MSMEs Performance } \\
\rightarrow \text { Poverty Level }\end{array}$ & $-0,637$ & 12.170 & 1,96 & $0.000 * * *$ \\
\hline$* *$ significant at $\alpha 5 \%$. & & & &
\end{tabular}

Partially, microcredit and MSMEs performance give negative and significant impact on the poverty level. Microcredit has a negative and significant effect on poverty levels. That is the better and flexible the mechanism of microcredit, the more people who can use microcredit that affects the decrease in poverty. MSMEs performance also has a negative and significant influence on poverty level. That is, the better the business performance run by the people will reduce the poverty rate.

The results of this study are in accordance with previous researches [3] [6] [7] which is found that microfinance has an effect on poverty reduction, where people can increase their income after using the loan from the bank.

The results of this study indicate that microcredit as an alternative financing for the poor is needed in the framework of community empowerment through business establishment in the micro, small and medium scale. With the effort, the community can earn income and can improve the welfare that ultimately reduces the poverty rate, especially for the affected people around Jatigede Reservoir, Sumedang, West Java.

\section{CONCLUSION}

Based on verificative analysis about the influence of microcredit and the performance of MSMEs to the level of poverty. Microcredit variable and MSMEs performance simultaneously influence poverty level variable.

Partially, each variable of microcredit and MSMEs Performance give negative and significant influence on the poverty level. That is the better and flexible the mechanism of microcredit, the more people who can use microcredit that affects the decrease in poverty. Also, the better the business performance performed by the community, the more income that will be obtained so as to reduce poverty.

\section{REFERENCES}

[1] Hartomo \& Aziz, A. 1997. Ilmu Sosial Dasar. Jakarta: Bumi Aksara

[2] Yunus, M. 2003. Expanding Microcredit Outreach to Reach The Millenium Development Goals. International Seminar on Attacking Poverty with Microcredit, Dhaka: 8

[3] Olutunla, G.T. \& Obamuyi, T.M. 2008. An Empirical Analysis of Factors associated with the profitability of small and medium enterprises in Nigeria. African Journal of business management, 2(11): 195-200.

[4] Babajide, A. \& Joseph, T. (2011). Microcredit and Business Performance in Nigeria: The Case of MFI finance Enterprises. International Journal of Current Research, 3(11): 068-075.

[5] Karay, J.C. 2012. Analisis Peran Lembaga Mikro Terhadap Pemberdayaan Usaha Mikro Kecil di Kabupaten Jayapura. Jurnal Ekonomi dan Bisnis, 2(1)

[6] Hossain, M.K. 2012. Measuring the impact of BRAC microfinance operations: A case study of a village. International Business Research, 5(4): 112 .

[7] Imtiaz, A., Mehmood, H.Z., Akram, W. \& Irfan, M. 2014. Impact of Microfinance on Poverty Reduction: A Case Study of District Faisalabad. Journal of Economics and Sustainable Development, 5(9). 
[8] Samer, S., Majid, I., Muhamad, M.R., Halim, S. \& Rashid, N. 2015. The Impact of Microfinance on Poverty Reduction: Empirical Evidence from Malaysian Perspective. Procedia- Social and Behavioral Sciences, 195: 721-728.

[9] Hidayat, H.S. 2007. Pengaruh lembaga Keuangan Mikro terhadap Prestasi Industri Kecil Rumah Tangga di Kabupaten Merangin. Doctoral dissertation, Tesis (unpublicated).

[10] Sabirin, S. 2001. Pemanfaatan Kredit Mikro untuk Mendorong Pertumbuhan Ekonomi Rakyat di dalam Era Otonomi Daerah. Orasi Ilmiah Lustrum IX Universitas Andalas. Padang. 